\title{
SLC6A4 Gene
}

National Cancer Institute

\section{Source}

National Cancer Institute. SLC6A4 Gene. NCI Thesaurus. Code C105874.

This gene is involved in serotonin transport. 